\title{
The Influence of Leadership Styles, Work Environment and Job Satisfaction of Employee Performance-Studies in the School of SMPN 10 Surabaya
}

\author{
${ }^{1}$ School of Business, Pelita, Indonesia \\ ${ }^{2}$ Department of Management Studies Program, Faculty of Economics, University of PGRI Adi Buana Surabaya, \\ Indonesia \\ Correspondence: Priyono, Department of Management Studies Program, Faculty of Economics, University of \\ PGRI Adi Buana Surabaya, Indonesia. Tel: 62-081-216-974-878. E-mail: priyono.unu_sidoarjo@yahoo.com
}

\author{
Received: May 4, 2015 Accepted: July 5, 2015 Online Published: December 29, 2015 \\ doi:10.5539/ies.v9n1p131 URL: http://dx.doi.org/10.5539/ies.v9n1p131
}

\begin{abstract}
This research aims to know and test the influence of leadership styles, work environment and job satisfaction of employees on performance.

Research methods with the use of a quantitative approach, the population in this study as many as 45 people while the sample in this research is 45 people. In this study the researchers data analysis using SPSS Statistical computer program version 20.0.

The results of this research is the leadership style has an impact on performance, the work environment also have an impact on performance, job satisfaction has an impact on performance, and leadership style, work environment and job satisfaction of influential performance signifiicant.
\end{abstract}

Keywords: leadership style, work environment, job satisfaction, the performance of employees

\section{Introduction}

In the last two decades, the concept of transactional and transformational evolved and gotten the attention of many academics and practitioners (Locander et al., 2002; Yammarino et al., 1993). According to Humphreys (2002) and Liu et al. (2003) caused the concept popularized by Bass in 1985, that can hold the concept of leadership that have a broad spectrum, including behavioral approaches, including situational contingency approach. The emergence of a reaction in the form of attitude, commitment, turnover intensi organization and job satisfaction decreases during the perception of job insecurity (Ashford et al., 1989; Rosenblatt \& Ruvio, 1996 in Wening \& Chirumbolo, 2005) found that job insecurity is correlated negatively with the performance and positive with the attendance.

Smithson and Lewis (2000) make sense of job insecurity as the psychological conditions of the people (employees) that shows a sense of confused or feel insecure because of changes in environmental conditions. This condition arises due to the type of work a moment or a work contract. The growing number of types of jobs with duration time is temporary or permanent, causing no other employees who are experiencing job insecurity.

Employee involvement is high and very strong partiality on the type of work done and really care about the type of work (Robbins, 2007). The theory is that by knowing the involvement of employees in the work, employees will be more motivated and more committed and more productive with their work.

Dessler (2009) stated performance appraisal employee performance evaluation as current or future relative to the standard of his achievements. Bernardin and Russel stating the performance assessment "A way to measure the contribution of individuals to their organizations." so it can be concluded that the performance assessment is a way of measuring individual contributions (employees) for their work in an organization or company.

Effective leadership is always using dominance, have self-assurance, affecting and featuring a high morality to increase levels of charismatic (Ivancevich et al., 2008, p. 213). 


\section{Literature Review}

\subsection{Previous Research}

Asmawati (2003), in his research stating that the variation of the teacher performance variables (Y) are able to explain. with free variables, either by direct leadership style (X 1), work environment (X 2), style support (X 3), style of delegation (X 4), of 0,861 or $86,1 \%$ whereas the rest (13.9) is affected by other variables.

Adi Joko (2003), in his research also revealed that with the number of $N=30$ in earned value $r=0,733$ count while the product results when the correlation $\mathrm{r}(\mathrm{r}$ table) on a significant $5 \%=0,361$ and on the level of interest of $1 \%=0,463$ which means $r$ calculate larger dar $r$ table at a rate of interest or importance as far as the $\% 1 \%$.

Research results from other countries in the context of the school has found the impact of strong leadership in the change development school (Hopkins 2001a; West, Jackson, Harris, \& Hopkins, 2000). Hopkins (2001b) highlights the importance of transforming leadership and learning practices in achieving improvements in schools.

Literature-literature on existing leadership also pointed out that the theories are the most popular model is transactional and transformational that has identified more than 20 years ago, (Burns, 1978; Hoy \& Miskel, 2008) stated lately return terms such as 'liberation' (Tampoe, 1998), 'educating' (Duignan \& McPherson, 1992), the 'invitation' (Stoll and Fink, 1996) and 'moral' leadership (Sergiovanni, 1992).

According to Brenninkmeyer and Spillane (2008, p. 436), a recent study declared the principal task of the adalahi someone who spends a lot of time to solve the problem of learning in school, and solve performance problems.

The real effect on the outcome of students at the school, and schools are effective, requires a leader who not only determine the direction but they also have values and practices that are consistent (Sergiovanni, 1995, p. 119). stating the effective leader is a proactive and continuous learning on school programs that are conducive to the growth of learning siswal. However, effective learning and administrative leadership required to carry out the process of change (Hoy \& Miskell, 2008).

\subsection{Basic Theory}

\subsubsection{Leadership Styles}

According to (Thoha, 2001, p. 227) leadership is an activity to influence the people they want to reach the destination point in the organization. Meanwhile, according to Ermaya (1999, p. 11) leadership is the ability of a leader to take control, leading, influencing the thoughts, feelings or behaviors of others to achieve the goals that have been set.

Empowering leadership is defined as behavior that is directed at the individual leader and the whole team, which consists of the delegation of authority to its employees, enhancing their independence and autonomy in decision making, coaching, information sharing, (Chen, Lam, \& Zhong, 2007; Kirkman \& Rosen, 1999; Konczak, Stelly, $\&$ Trusty, 2000). In an organization that rely more on teamwork, and the complexity of the work, there is a trend of increasing interest in empowering leadership, scholars and actors (Arnold, Arad, Rhoades, \& Drasgow, 2000; Seibert, Silver, \& Randolph, 2004) for high performance (maximum), it needs it needs a leader capable of managing its human resources. It is supported by a statement Alberto et al., in the Religious (2010) States that a strong leadership style will generate a positive effect on performance. Leaders have a way of influencing others or subordinates in such a way that the person is willing to do the will of the leadership to achieve company goals.

Models of leadership according to Fiedler (1967) that is a model that assumes that the contribution was a leader against the effectiveness of the performance of the Group's leader depends on the manner or style of leadership itself.

Ivansevich (2008) States that leadership is the ability of a person to use the influence of the environment or the situation of the Organization, to produce the effect of meaning and impact on achievement of goals that are challenging.

Robbin (2002) defines leadership as the ability to influence a group to achieve a goal. Meanwhile, and according to Isaac. and Hendry. (2003), leadership is a person's ability to control or influence others or society towards achievement of specific departments.

Of some opinions about leadership definition above, can be summed up basically contains the common assumption in common such as: (1) in a group phenomenon involving interaction between two or more persons, (2) involved in the process of influence, where the influence of the accidental use by subordinate leaders. In 
addition to the common assumption, the similarities in this definition also has the distinction of being public also like: (1) anyone who uses influence, (2) the goal rather than trying to influence, and (3) how to influence it used.

Situational Leadership model developed by business and Blanchard. Robbins and Judge (2007) is a situational leadership in Unions based on a business approach, and identify four specific behaviour Blanchard leadership very directive, participatory, lsampai support. and the most effective behavior depends on the ability and readiness of the followers. While the readiness in this context refers to the followers who have the ability and the will to accomplish a specific task.

Path goal theory (the theory of) leadership has been developed to explain how a leader's behavior affects performance and job satisfaction. This theory first stated by Evans (1970) and House (1971). House (1971) has been formulating these theories with a version that is more thoroughly, including situational variables. The theory further stated by some writers as Evans (1974); House and Dessler (1974); House and Mitchell (1974) and House (1996).

Based on the description of leadership at the top, it seems that the key elements of leadership is that person's influence and role in leadership is the attempt of a person playing the role of a leader to influence others in the Organization/institution to achieve the goal. According to Wirawan, affect the process by people who are looking for a change in attitude, behavior, values, norms, beliefs, thoughts, and the purpose of the affected people are systematically.

\subsubsection{Work Environment}

According to Alex Soemadji Nitisemito (2001: 110) "work environment, is everything that exists around the employee and may affect the employee in performing his or her duties.

According to Agus Ahyari (2004: 128) defines the working environment is the environment where the employees perform tasks and work everyday.

\subsubsection{Job Satisfaction}

According to Weihrich and Koontz (2005) (in Sinambela et al., 2012, p. 256). Job satisfaction refers to the experience of pleasure or joy felt by someone when what is desired is reached.

According to Handoko (2000, p. 195), job satisfaction is the emotional state employees. Job satisfaction reflects one's feelings towards his work. This appears in the positive attitude of the employees towards his job and everything found in the neighborhood. While Newtrom (1998, p. 256) stated that job satisfaction is a feeling employees about something fun.

According to Sunyoto (2012, p.210), job satisfaction is the employee's emotional state, saw her job successfully.

According to Martoyo (2002, p. 124), job satisfaction is the State employee emotions that occur or there is no intersection between the values just replying to the level of the employees work and value of revenge to win the employee in question.

From some of the opinions above it can be concluded that job satisfaction reflects feelings toward his job. Looks in a positive attitude toward work and all employees in their environment

\subsection{The Conceptual Framework}

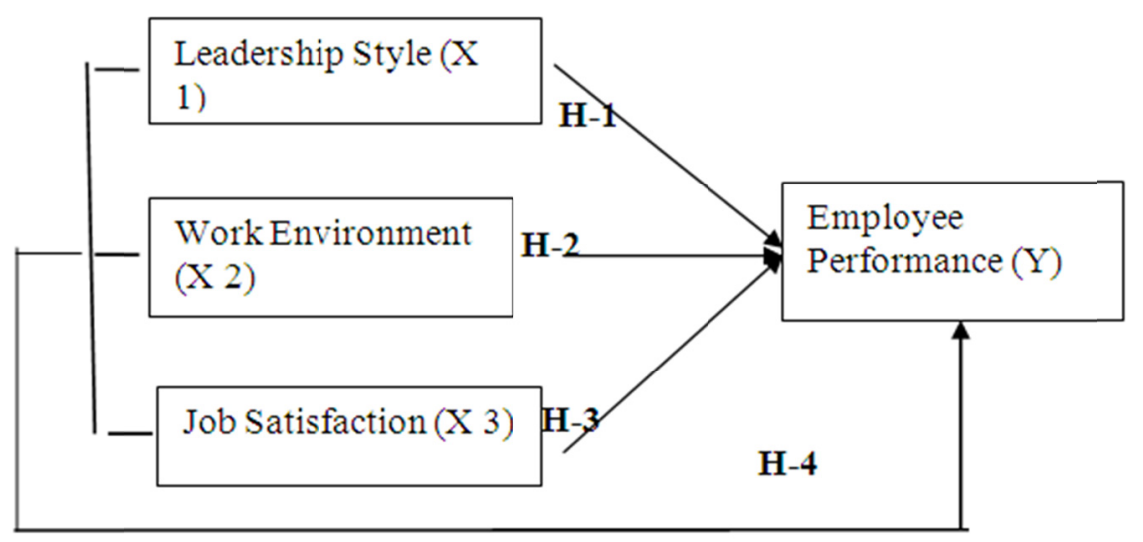




\section{Methods}

This type of research is research descriptive research and quantitative approach uses survey method. According to Singarimbun, (1995) a survey of the method of research is research that takes a sample of the questionnaire population and uses as a staple in the means of data collection. This research will then figure out the influence of leadership styles between variables that have been defined that explain the influence of leadership styles, work environment, job satisfaction on performance of employees in the Office SMPN 10.

This research was conducted at the Office of SMP 10 Surabaya, the population in this study as many as 45 people. Whereas samples taken as many as 45 people, with a random stratified sampling techniques in data retrieval. his survey methods and using questionnaires.

Instruments used in collecting data must meet two conditions, namely, validity and reliability, all applicable results and reliability. So that the instrument can be used in the research. Technical analysis in this research is a descriptive analysis and statistical analysis of Linear analysis using multiple inferential, and test the hypothesis (F-test and t-test).

1) Employee performance variables (Y 1)

Employee performance is the level and ability of employees in achieving the requirements of the work that has been directed by the Chairman or the head of the school, with the following indicators:

Loyalty, accomplishment, responsibility, work, honesty, obedience,

2) The initiative and Leadership

Principal Leadership Style Variables (X 1)

Leadership style indicators according to Coleman (2006, p. 65), namely as follows: Visionary, Mentor, Affiliate, democratic Communication

The Work EnvironmentVariable (X 2)

A new Factor influencing factors - the work environment is very broad. Based on a description of what is meant by work environment, it will be able to put forward several factors that are included in the working environment and of its effects on the morale and work motivation.

According to Nitisemito (2001, pp. 111-117), some of the factors that affect the work environment include: coloring, hygiene, water, lighting, music, security. Noise

\section{Job Satisfaction Variables (X 3)}

Soejono (2005, p. 27), measuring job satisfaction by using indicators, among other things, such as employees: payment of salary and wages, the work itself.

\section{Results of the Research and the Discussion}

\subsection{The Characteristics of the Respondents}

Characteristics of respondents, the majority of respondents are female with a total of 16 respondents (39.1 per cent), whereas for women totaled 29 respondents (61\%). Data characteristics of respondents based on their age, most ages $41-50$ years as many as 12 people ( 22.6 percent), followed by respondents aged 30 years as many as 15 people $(25 \%)$ and the rest as much as $3(9 \%)$ of respondents aged $31-40$ years and 15 respondents $(22.7 \%)$ who are over 50 years old. Educational level of respondents researched is diverse ranging from upper-level secondary school (SLTA) to graduates of the S-2. Uneven composition, education of respondents with educational administration, as many as 10 people (38.6\%) and an educated scholar S-1 with the amount of 20 respondents (34.1\%) as well as the S-2 education as many as 15 people.

Linear regression analysis is used to find out the influence of leadership styles (X 1), work environment (X 2), and job satisfaction (X 3) on performance of employees (Y) in SMPN 10. After knowing the results of the test assumptions. Further analysis will be performed multiple linear regression. To simplify the calculations using computer programs with the help of SPSS version 20.0 tests were conducted as follows: 
Table 1. Multiple Linear regression analysis

\begin{tabular}{ll}
\hline Variable & Unstandartized Coefficients (B) \\
\hline Constant & 3.010 \\
Leadership Style & 0.782 \\
Work Environment & 2.558 \\
Job Satisfaction & 0.625 \\
R & $=0.969$ \\
R Square & $=0.939$ \\
Adjusted R Square & $=0.935$ \\
$\alpha$ & $=0.005$ \\
Description: & \\
-The amount of Data (n) & $: 45$ \\
-The Dependent variable & $:$ Performance \\
\hline
\end{tabular}

Source: SPSS Output Attachment, Multiple Linear Regression, Data processed.

From Table 1, the regression equation is obtained as follows:

$\mathrm{Y}=0.782+3.010$ seriously $\mathrm{x} 1+\mathrm{x} 2+\mathrm{X} 30.6252 .558$

Based on these equations, it can be described as follows:

a. A constant (a) $=3.010$, indicates the magnitude of the performance, if the style of Leadership, work environment and job satisfaction of zero, then the performance of 3,010 units.

b. Leadership Style of regression Coefficient 0.782 shows the magnitude of the effect on the regression coefficient of performance, marked positive Leadership Style shows a direct effect on performance, which means that any increase in the style of Leadership will lead to increased Performance of 0.782 units.

c. The regression coefficient of the working environment of 2.558 shows the magnitude of the influence of work environment on performance, regression coefficient marked a positive work environment demonstrate a direct effect on performance, which means that any increase in the work environment will lead to the increased Performance of 2.558 units.

d. Job satisfaction of regression Coefficient 0.888 shows the magnitude of the influence of job satisfaction toward Performance regression coefficient marked positive indicates job satisfaction direct effect on performance, which means any increase in job satisfaction will lead to increased Performance of 0.888 units.

e. The regression coefficient of job satisfaction of 0.625 shows the magnitude of the influence of job satisfaction toward Performance regression coefficient marked positive indicates job satisfaction direct effect on performance, which means any increase in job satisfaction will lead to increased Performance of 0.625 units.

f. The correlation Coefficient $(\mathrm{R})$ of 0.969 ; indicates that there is a very strong relationship between Leadership Style, work environment and job satisfaction on performance.

g. Determination coefficient Values (R square) of 0.939. This figure shows that the style of leadership, work environment and job satisfaction can account for the variation or to contribute towards the purchase Decision variables of $93.9 \%$, while the rest amounted to $6.1 \%$ are caused by other variables that are not included in the study.

\subsection{Discussion}

\subsubsection{The Leadership of the Effect on Performance}

The results of the regression analysis proves that the leadership style of influential significantly to performance proven employees from test-t obtained $t$ calculate $=655$-value sig. 0.026 . This is in accordance with the opinion of Hasibuan (2004, p. 197) stating that "leadership is the art of a leader influences the behavior of the subordinate, to cooperate and work for productivity to achieve the objectives of the organization." Leadership is 
the ability by owned to influence the activities of a person or entity, in order that people are willing to work effectively and efficiently in achieving a goal that has been specified in the particular situation.

The results of this research also supports previous research results from Brenninkmeyer and Spillane (2008, p. 436), which States that the principal as someone who spends a lot of time to solve the problem of learning in school, and its performance in solving problems that have a real influence on the outcome of students at the school. It is clear from the literature, and of the effective schools, is that a successful leader will not only determine the direction of but also the values and practices that are consistent with a Model of the school, so the "goal that initially may seem to be split into integral" (Sergiovanni, 1995, p. 119). Effective leaders are proactive and seek assistance as needed. They also continued to study the Program and school culture that is conducive to learning and professional growth. However, an effective learning and administrative Leadership required to carry out the process of change (Hoy \& Miskell, 2008).

\subsubsection{Work Environment Influence on Performance}

The results of the analysis proved a significant influential work environment on performance clerk acceptable significantly evident from testing-t obtained $t$ calculate $=15.517$ value sig. 0.000 . This is in accordance with the opinion of Nitisemito (2001, p. 183) which says that the work environment is one that exists surrounding the workers or everything who wants someone who can affect the work itself in implement tasks-tasks that are charged.

Many factors affect the performance of employees in a work such as working environment. To implement the job effectively and efficiently required the existence of a working environment capable of supporting implementation work properly. Adjustment of a good system of production one is not supported with a satisfying work environment within the school. Schoolgirl in a work environment will have a direct influence against an employee who worked in the schools. The emergence of a reaction in the form of attitude, intensive turnover, organizational commitment and job satisfaction are decreased over the existence of the perception of job insecurity (Ashford et al., 1989; Rosenblatt \& Ruvio, 1996, in Wening, 2005 and Chirumbolo, 2005) found that job insecurity is correlated negatively with the performance and positive with the absences.

\subsubsection{Job Satisfaction Influence on Performance}

The regression coefficient of job satisfaction of 0.673 shows the magnitude of the influence of job satisfaction toward performance, multiple regression coefficients showed positive job satisfaction direct effect on performance, which means any increase in job satisfaction will lead to increased Performance of 0.673 units. Regression Coefficients and the job satisfaction of 0.625 shows the magnitude of the influence of job satisfaction toward Performance regression coefficient marked positive indicates job satisfaction direct effect on performance, which means any increase in job satisfaction will lead to increased Performance of 0.625 units. The results of this analysis are also in accordance with the thought of Smithson and Lewis (2000) making sense of job insecurity as the psychological condition of a person (employee) that shows a sense of confused or feel insecure because of the changing environmental conditions. This condition arises due to the type of work which is momentary or employment contract. The increasing number of types of jobs with duration time that temporarily or permanently, causing no more employees who are experiencing job insecurity.

The results of this analysis are also in accordance with the opinion of the Sunyoto (2012, p. 210) job satisfaction is a pleasant emotional state or not sites where employees looked at job. Martoyo (2002, p. 124) pointed that job satisfaction is the emotional state employees which occur or not intersection between the values of reply only to the level of employee work values winning retribution are desired by the concerned employees. Reply just financial but could either be non-financial i.e. awards and attention or compassion management.

\subsubsection{Leadership Styles Influence on Job Satisfaction and Performance}

The value of the coefficient of determination (R square) of 0.939 . This figure shows that the style of leadership, work environment and job satisfaction can account for the variation or to contribute towards the purchase Decision variables of $93,9 \%$, while the rest amounted to $6.1 \%$ are caused by other variables that are not included in the study

Leadership style, work environment and job satisfaction significant employees on performance effect is evident from the results of the test $\mathrm{F}$ obtained $\mathrm{F}$ count $=211.047$ with a value of sig. $=0.000$. Leadership is one of the important factor, since the factors of leadership can provide a meaningful influence on performance clerk because of a leadership plan, inform, create, and evaluate the various decisions that have to be implemented in the schools.

An organization's success in achieving the objectives is also inseparable from the working environment factors. 
The work environment is everything that exists around the workers and could affect him in the exercise of the duties assessed, job satisfaction reflects one's feelings towards his work. This appears to be in a positive attitude towards employees work and everything encountered in the environment of work. When employees have a positive attitude toward work and everything that is encountered in the environment it works then the goals can be achieved.

\subsubsection{The Limitations of the Research}

Some limitations of the research that can be drawn from this study are as follows:

1) Not all potential respondents were willing to become the respondents in this study, because of the busyness and time limitations and fear of the respondents that the answers given will affect him.

2) In this study has limitations on the number of respondents was still a little bit of .people, so expect further research to do greater research respondents or can do research population/census.

3) The limited availability of supporting data obtained from the company and are not all the latest data.

4) How to. This research is limited to discussion of the three independent variables, should be expanded by adding an intervening variable abilities or competence of the employees that can affect the performance of the employee's work.

5) At the place of work variable discipline (X 3) and the performance appraisal process (Y) or the distribution of the questionnaires is carried out directly by the employees who responded by using self-assessment so hopefully in the next research assessment can be done by the leadership

\section{Conclusions and Recommendations}

\subsection{Conclusions}

Based on the study and analysis of the statistical data-data that is retrieved in order to test the hypothesis presented in this study, then finally the authors conclude things as follows:

Leadership style has an impact on performance, from hypothesis testing using test $-\mathrm{t}$ obtained $\mathrm{t}$ calculate $=$ 655 -value sig. 0.026 so $(0,026<0.05)$ then the hypothesis received significantly.

The work environment has an influence on purchasing decisions, from hypothesis testing using test $-\mathrm{t}$ obtained $\mathrm{t}$ calculate $=15.517 \mathrm{sig}$ value 0.000 . so $(0.000<0.05)$ then the hypothesis received significantly.

Job satisfaction has influence on purchasing decisions, from hypothesis testing using test- $\mathrm{t}, \mathrm{t}=2.458$ calculating earned value sig. 0.018 so $(0.018<0.05)$ then the hypothesis received significantly.

Leadership style, work environment and job satisfaction significant employees on performance effect. $\mathrm{F}$ test results obtained $\mathrm{F}$ count $=211.047$ with a value of sig. $=0.000(0.000 \leq 0.05)$.

\subsection{Advice}

As for the suggestions put forward in this study researchers are as follows:

\subsubsection{Leadership Styles}

The necessity of enhancing the role of a leader in improving the performance of employees in SMPN 10. The leadership or the principal could be paying attention and direction to subordinate officers who could steer employees toward a vision firmly that exists in all schools, capable of being a good supervisor so that employees can develop their ability in order to improve the performance of employees with maximum.

\subsubsection{Working Environment}

Employee work environment conditions need to be improved to make it more conducive working atmosphere so that it is able to provide a comfortable and positive impact on the development of employee performance.

\subsubsection{Job Satisfaction}

The school at SMPN 10 Surabaya should pay more attention to employees so that the relationship between fellow officers and subordinates with the leader could give each other motivation, work together and communicate with each other very well. In order for employees to feel satisfied so that it can improve its performance. 


\section{References}

ADI Joko Sudarwanto. (2003). The influence of work environment On Employee Accomplishments section in CV Grace Jaya Universe Surabaya. Thesis.

Agus, A. (2002). Production Planning Management System of production. Yogyakarta, BPFE.

Arikunto, S. (2006). Research Procedures: A Practical Approach. Mold 15, Rineka Jakarta: Copyright.

Aris, R., Harrison, C., \& Humphreys, C. (2002). Safety and child contact: An analysis of the role of child contact centers in the context of domestic violence and child welfare concerns. London: Centre for the Study of Safety and well-being, the University of Warwick.

Arnold, J. J., Arad, S., Rhoades, J. A., \& Drasgow, F. (2000). The Empowering Leadership Questionnaire: The construction and validation of a new scale for measuring leader behaviors. Journal of Organizational Behavior 21 , 249-269. http://dx.doi.org/10.1002/(SICI)1099-1379(200005)21:3<249::AID-JOB10>3.0.CO;2-\#

Ashford, S. J., Lee, C., \& Bobko, P. (1989). Content, cause, and consequences of job insecurity: A theory-based measure and substantive test. Academy of Management Journal, 32, 803-805. http://dx.doi.org/10.2307/256569

Asmawati. (2003). The influence of Factors on the performance of teacher leadership style on the IPH School in Surabaya. Thesis.

Brenninkmeyer, L. D., \& Spillane. (2008). Problem-solving processes of expert and typical school principals: A quantitative look. School Leadership and Management, 28(5), 435-468. http://dx.doi.org/10.1080/13632430802517209

Burns, J. M. (1978). Leadership. New York: Harper and Row.

Chen, Z., Lam, W., \& Zhong, J. A. (2007). Leader-member Exchange and Member Performance: A New Look at Individual-level Negative Feedback-seeking Behavior and Team-level Climate Empowerment. Journal of Applied Psychology, 92(1), 202-212. http://dx.doi.org/10.1037/0021-9010.92.1.202

Coleman, D. (2006). Client Personality, Working Alliance and Outcome: A Pilot Study. Social Work in Mental Health, 4(4), 83-98. http://dx.doi.org/10.1300/J200v04n04_06

Coleman, D. (2006). Therapist-Client Five-Factor Personality Similarity: A Brief Report. Bulletin of the Menninger Clinic, 70(3), 232-241. http://dx.doi.org/10.1521/bumc.2006.70.3.232

Dessler, G. (1997). Personnel Management: Modern techniques and Concepts (Translation, 3rd ed.). Jakarta, Eason.

Duignan, P. A., \& Macpherson, J. T. (1992). Educative leadership: A practical theory for new administrators and managers. London: Falmer Press.

Ermaya, S. (1997). Leaders and Leadership Government. PT. Gramedia Pustaka, Jakarta.

Evans, M. G. (1970). The effects of supervisory behavior on the path-goal relationships. Organizational Behavior and Human Performance, 5, 277-298. http://dx.doi.org/10.1016/0030-5073(70)90021-8

Fiedler, F. E. (1967). A theory of leadership effectiveness. New York, NY: McGraw-Hill.

Ghozali. (2006). Analisys Multivariate Applications with the SPSS program UNDIP Semarang.

Goleman, D. (2006). The Intelligence Emosioanal. PT Gramadia Jakarta, Main Library,

Handoko, H. T. (2001). Human resources management. BPFE. Jogyakarta.

Hasibuan, M. S. (2004). Human resources management. The Revision of the Earth Edition Revised, Jakarta

Hopkins, D. (2001a). School improvement for real. London: Falmer Press. http://dx.doi.org/10.4324/9780203165799

Hopkins, D. (2001b). Meeting the challenge: an improvement guide for schools facing challenging circumstances. London: DfES.

House, R. J. (1971). A path-goal theory of leader effectiveness. Administrative Science Quarterly, 16, 321-338. http://dx.doi.org/10.2307/2391905

House, R. J., \& Dessler, G. (1974). The path-goal theory of leadership: Some post-hoc and a priori tests. In J. Hunt, \& L. Larson (Eds.), Contingency approaches to leadership (pp. 29-55). Carbondale, IL: Southern 
Illinois University Press.

House, R. J., \& Mitchell, T. R. (1974). Path-goal theory of leadership. Journal of Contemporary Business, 3, 81-97.

Hoy, D., \& Miskel, C. (2008). Educational Administration: Theory, Research, and Practice. Boston: McGraw Hill companies.

Humphreys, J. H. (2002). Trnasformational leader behavior, proximity and successful services marketing. Journal of Services Marketing, 16(6), 487-502. http://dx.doi.org/10.1108/08876040210443373

Ivancevich, K., John, M., \& Matteson. (2008). Organizational Behavior and Management. Jakarta: Eason

Kirkman, B. L., \& Rosen, B. (1999). Beyond self-management: Antecedents and consequences of team empowerment. Academy of Management Journal, 42, 58-74. http://dx.doi.org/10.2307/256874

Konczak, L. J., Stelly, D.J., \& Trusty, M. L. (2000). Defining and measuring empowering leader behaviors: Development of an upward feedback instrument. Educational and Psychological Measurement, 60, 301-313. http://dx.doi.org/10.1177/00131640021970420

Liu, W., Lepak, D. P., Takeuchi, R., \& Sims, H. P. (2003). Matching leadership styles with employment modes: Strategic human resource management perspective. Human Resource Management Review, 13, $127-152$. http://dx.doi.org/10.1016/S1053-4822(02)00102-X

Locander, W. B., Hamilton, F., Ladik, D., \& Stuart, J. (2002). Developing a leadership-rich culture: The missing link to creating a market-focused organization. Journal of Market-Focused Management, 5, 149-163. http://dx.doi.org/10.1023/A:1014048111158

Martoyo, S. (2002). Human resources management (4th ed.). Yogyakarta, BPFE.

Nitisemito, A. S. (2001). Personnel management, human resources management (3rd ed.). Ghalia Indonesia, Jakarta.

Robbins, S. P. (2006). Organizational behavior. PT Index, Jakarta: Gramedia Group.

Robbins, S. P., \& Judge, F. Y. (2007). Organizational Behavior (12th ed.). Prentice Hall

Seibert, S. E., Silver, S. R., \& Randolph, W. A. (2004). Taking empowerment to the next level: A multiple-level model of empowerment, performance and satisfaction. Academy of Management Journal, 47, 332-349. http://dx.doi.org/10.2307/20159585

Sergiovanni, T. J. (1992). Moral leadership: Getting to the heart of school improvement. San Francisco: Jossey-Bass.

Sergiovanni, T. J. (1995). The head leachership: A reflective practice perspective. Boston: Allyn and Bacon.

Sergiovanni, T. J. (1998). Value-added leadership: How to get extraordinary performance in schools. San Diego, CA: Harcourt Brace Jovanovich, Publishers.

Siagian, S. P. (2012). Human resource management. Earth Literacy, Jakarta.

Sinambela et al. (2012). Employee Performance measurement and Theoretical implications (1st ed.). Yogyakarta: Graha Science.

Singarimbun, M. (2006). Survey Research Methods. LP3ES, Jakarta

Smithson, A., \& Lewis, S. (2000). Job insecurity is the changing psychological contract? Young people's expectations of work. Personnel Review, 29(6), 680-695. http://dx.doi.org/10.1108/00483480010296465

Stoll, L., \& Fink, D. (1996). Changing our schools. London: Open University Press.

Tampoe, M. (1998). Liberating leadership. London: The Industrial Society

Weihrich, H., \& Koontz, H. (2005). Management: A Global Perspective (11th ed.). New Delhi: Tata McGraw-Hill Publishing Co. Ltd 600.

Wening, N. (2005). Effect of Job Insecurity (Job Insecurity) As Restructuring Impact on Job Satisfaction, Organizational Commitment and Intention Exit Survivor. Performance Journal STIE Widya Wiwaha Yogyakarta, 9(2), 135-147.

Yammarino, F. J., Spangler, W. D., \& Bass, B. M. (1993). Transformational leadership and performance: A longitudinal investigation. Leadership Quarterly, $4(1), \quad$ 81-102. http://dx.doi.org/10.1016/1048-9843(93)90005-E 
Yukl, G. (2005). Leadership in the organization (4th ed.). Jakarta: Ind.

\section{Copyrights}

Copyright for this article is retained by the author(s), with first publication rights granted to the journal.

This is an open-access article distributed under the terms and conditions of the Creative Commons Attribution license (http://creativecommons.org/licenses/by/3.0/). 